\title{
Effect of in ovo injection with L-arginine on productive and physiological traits of Japanese quail
}

\author{
H.J. Al-Daraji ${ }^{\#}$ A.A. Al-Mashadani, W.K. Al-Hayani, A.S. Al-Hassani \& H.A. Mirza \\ University of Baghdad, College of Agriculture, Department of Animal Resources, Baghdad, Iraq
}

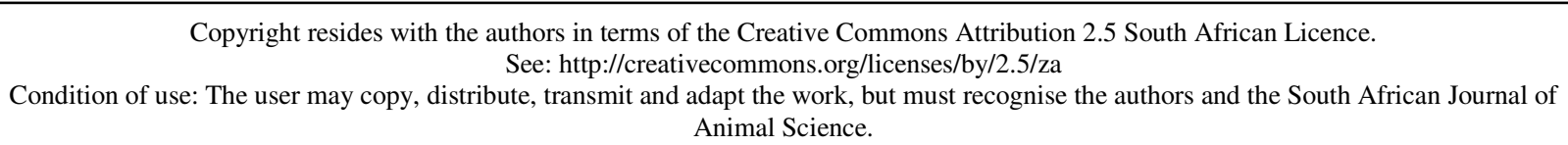

\begin{abstract}
This study evaluated the influence of administering different levels of L-arginine into eggs of 0-dayold Japanese quail embryos. On day 0 of incubation, 480 eggs (120 for each treatment group) were injected with $0 \%$ arginine (C group), $1 \%$ arginine (T1), 2\% arginine (T2) or 3\% arginine (T3). After hatching, 336 quail chicks ( 84 chicks produced from each in ovo injection treatment) were placed in an experimental quail house and allocated to four treatment groups of three replicates, with 16 quail chicks for each replicate. Traits involved in this study were hatchability rate, initial body weight (7 days of age), final body weight (42 days old), feed intake, weight gain, feed conversion ratio and blood serum glucose, protein, cholesterol, total lipids, triglycerides, calcium and phosphorus concentrations, and proportional weights of the carcass, breast, legs, backbone, wings, neck, abdominal fat, liver, heart and gizzard. Results revealed that in ovo injection with different levels of L-arginine on day 0 of incubation resulted in significant increases in the hatchability rate, initial body weight, final body weight, feed conversion ratio, and blood serum glucose, protein, total protein, calcium and phosphorus concentrations, as well as the proportional weights of the carcass, breast, legs, liver, heart and gizzard. However, there was no significant difference in feed intake between treatment groups. Significant decreases were recorded in blood serum cholesterol, total lipids and triglyceride concentrations, and proportional weights of the backbone, wings and abdominal fat. In conclusion, the inoculation of different levels of L-arginine into eggs of 0-day-old quail embryos, especially at the levels of $2 \%$ and 3\% arginine, resulted in a significant improvement in the productive and physiological performance of the quail. Hence in ovo injection with L-arginine could be used as a tool for enhancing the hatchability rate and productive performance of quail hatched from the egg.
\end{abstract}

Keywords: Coturnix coturnix japonica, egg, incubation, in ovo fed avian neonate, nutrition

\# Corresponding author: prof.hazimaldaraji@yahoo.com

\section{Introduction}

Various factors play important roles in birds in influencing hatchability efficiency and growth performance during embryonic and post-hatch life, such as genetic make-up, egg characteristics and incubation environment (Narushin \& Romanov, 2002; Petek et al., 2003; Abiola et al., 2008). Hatching drastically changes the way chicks retrieve nutrients. In the embryo, yolk lipids are transported directly into the blood by endocytosis (dos Santos et al., 2010), but after hatching, the yolk content is absorbed through both the yolk sac membrane and the Meckel's diverticulum, and is digested and absorbed from the intestinal tract. At hatch the energy reserves in the yolk sac may not be sufficient to supply in the maintenance energy requirements of a chick (Dibner et al., 1998), and fasting effects may develop before the bird is removed from the hatchery. However, despite being capable of ingesting feed, the intestinal tract of the chick is still immature (Uni et al., 2003). Ohta et al. (1999) reported that the injection of an amino acid mixture into growing embryos in broiler breeder eggs resulted in a higher body weight at hatch and at $56 \mathrm{~d}$ of age compared with chick from control embryos. Ohta et al. (2001) suggested that the increase in hatching weight of 7-day-old embryos injected with amino acids may have been owing to a higher content of amino acids in the yolk or the better utilization of amino acids by the embryo. Foye et al. (2006) observed a higher body 
weight, and thigh and breast weights in day-old turkeys when they were inoculated at $23 \mathrm{~d}$ of incubation with egg-derived protein. Arginine is a basic amino acid, and is classified as conditionally essential. One of its main functions is its participation in protein synthesis. Arginine is involved in a number of other metabolic functions in the body, such as its potential to be converted to glucose (hence its classification as a glycogenic acid), and its ability to be catabolized to produce energy (Tong \& Barbul, 2004). Arginine is utilized in a number of metabolic pathways that produce a variety of biologically active compounds, such as nitric oxide, creatine, agmatine, glutamate, polyamines, ornithine and citrulline (Wu \& Morris, 1998).

Al-Murrani (1978) suggested that differences in protein content of eggs at days 0 and 7 of incubation could affect the growth of embryos. In addition, the administration of vitamin D precursor into eggs has been done from day 0 of incubation in Japanese quail (Elaroussi et al., 1993). If amino acid administration is possible before incubation, it may be advantageous. Owing to the importance of hatchability and early post hatch growth on the market size of birds, a study was undertaken to examine the effect of in ovo injection of L-arginine on hatchability, productive performance, carcass traits and physiological performance of Japanese quails (Coturnix coturnix japonica).

\section{Materials and Methods}

An experiment was conducted utilizing 480 fertilized commercial eggs of Japanese quail. All eggs were obtained from the same breeder flock and were laid within a 24-hour period. These eggs were randomly allocated to four treatment groups of 120 eggs each, such that the weight distribution profile among the four treatment groups was identical. Through in ovo supplementation, L-arginine was administered to the fertile eggs on day 0 of incubation. The in ovo injection solutions were $0 \% \mathrm{~L}$-arginine (sterile distilled water; control group); $1 \%$ L-arginine $(1 \mathrm{~g} \mathrm{~L}$-arginine $/ 100 \mathrm{~mL}$ sterile distilled water; T1); $2 \%$ arginine $(2 \mathrm{~g} \mathrm{~L}$ arginine/100 mL sterile distilled water; T2); 3\% L-arginine (3 g arginine/100 mL sterile distilled water; T3). L-arginine was provided by Qualikems Fine Chemicals Pvt, Ltd (5531, Basti Harphool Singh, Sadar Thana Road, Delhi-06). A hole was incised using an automatic needle (Figure 1), and $0.5 \mathrm{~mL}$ of the L-arginine solutions was injected at a depth of about $15 \mathrm{~mm}$ into the air cell using a 23-gauge needle. The injection site was disinfected with $70 \%$ ethanol before and after injection, sealed with nail paint (Figure 2) and transferred to incubating baskets in an incubator to complete the hatching process.

After $18 \mathrm{~d}$ of incubation, hatched quail chicks were removed from the incubator to determine hatchability rate. The chicks were then transported to an experimental house. The day-old chicks (336 chicks; 84 chicks from each in ovo injection treatment) were evenly distributed into the same treatment groups (four in ovo injection treatments) with three replicates per group and 28 chicks per replicate. For six weeks (duration of experiment) the quails were fed a diet containing $210 \mathrm{~g}$ protein $/ \mathrm{kg}$ and $12.08 \mathrm{MJ}$ metabolizable energy $/ \mathrm{kg}$. The quail were allowed free access to food and water and housed in wire cages containing 28 quails each. A regimen of $17 \mathrm{~h}$ constant lighting and continuous ventilation was provided, and all birds were kept under uniform management conditions throughout the experimental period.

Production traits measured in this study were initial body weight (7 days old), final body weight (42 days of age), feed intake, body weight gain and feed conversion ratio. The latter three traits were determined weekly and the data presented as a total mean for the whole experimental period (6 weeks).

At the end of experiment, blood samples were collected from 18 birds in each treatment (6 birds from each replicate). Blood was collected from the jugular vein (Al-Daraji et al., 2008) to ensure a free flow. A pooled blood sample for each replicate per treatment was analysed for serum chemistry traits. After overnight clotting at $4{ }^{\circ} \mathrm{C}$, the samples were centrifuged for $20 \mathrm{~min}$ at $4000 \mathrm{x} g$. The separated serum was transferred to a laboratory and was analysed for glucose, total protein, cholesterol, total lipids, triglycerides, calcium and phosphorus concentrations. Blood traits measured in this study were analysed according to the standard methods as reported by Al-Daraji et al. (2008).

On day 42 after hatching, feed was withdrawn overnight from all birds to facilitate gut clearance. After that the birds were weighed to obtain live body weight. The birds were then slaughtered, defeathered and processed (removal of gastrointestinal tract). The carcasses were stored at $4{ }^{\circ} \mathrm{C}$ for $24 \mathrm{~h}$, and then weighed. The carcasses were dissected and the weights of the liver, heart, gizzard, breast, legs, backbone, wings, neck and abdominal fat were obtained to determine the relative percentages of these carcass components.

Statistical analysis was carried out using a complete randomized design (Steel \& Torrie, 1980). These data were subjected to ANOVA according to GLM procedure of SAS software (SAS, 2000). The significant 
differences among means were determined by using Duncan's multiple range test. Differences among treatment means were compared at $P \leq 0.05$.

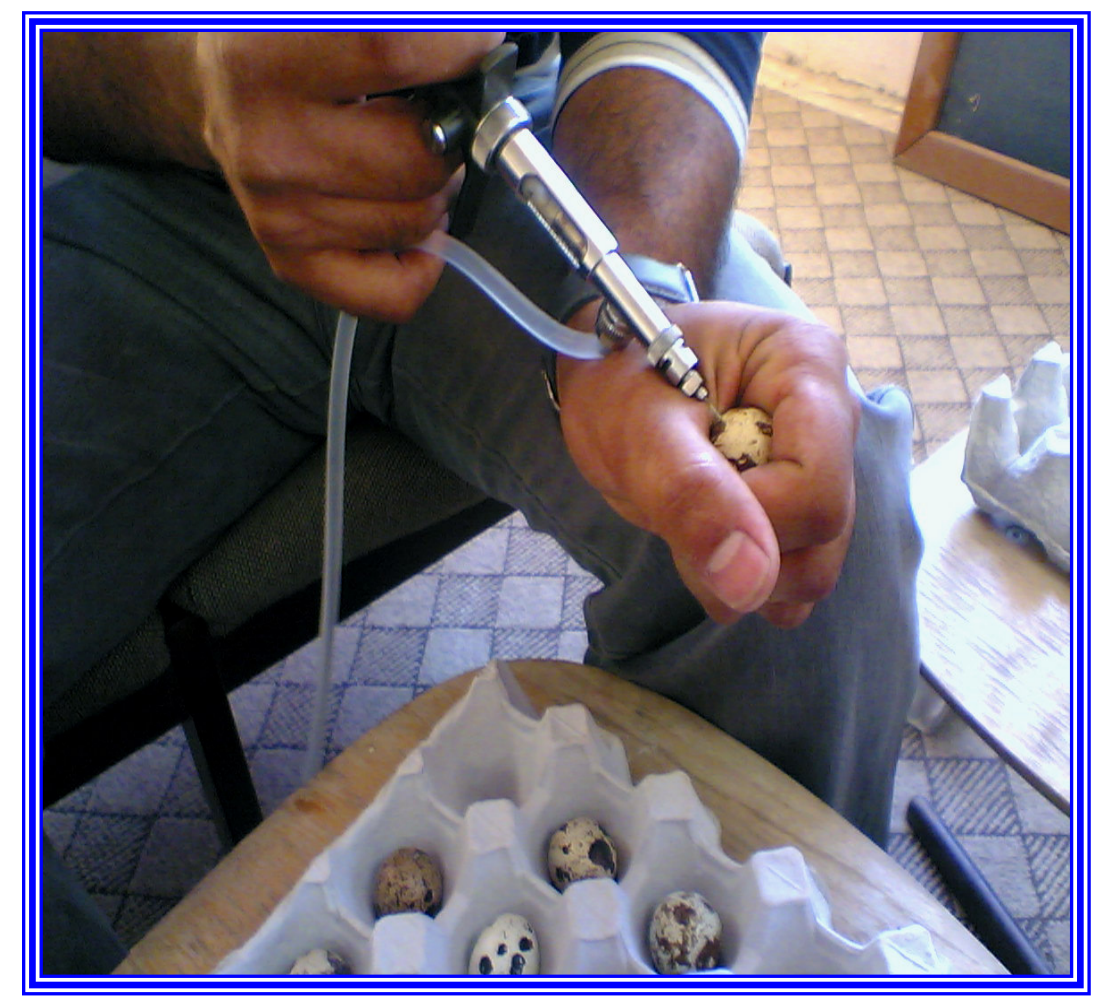

Figure 1 In ovo injection of L- arginine with automatic syringe.

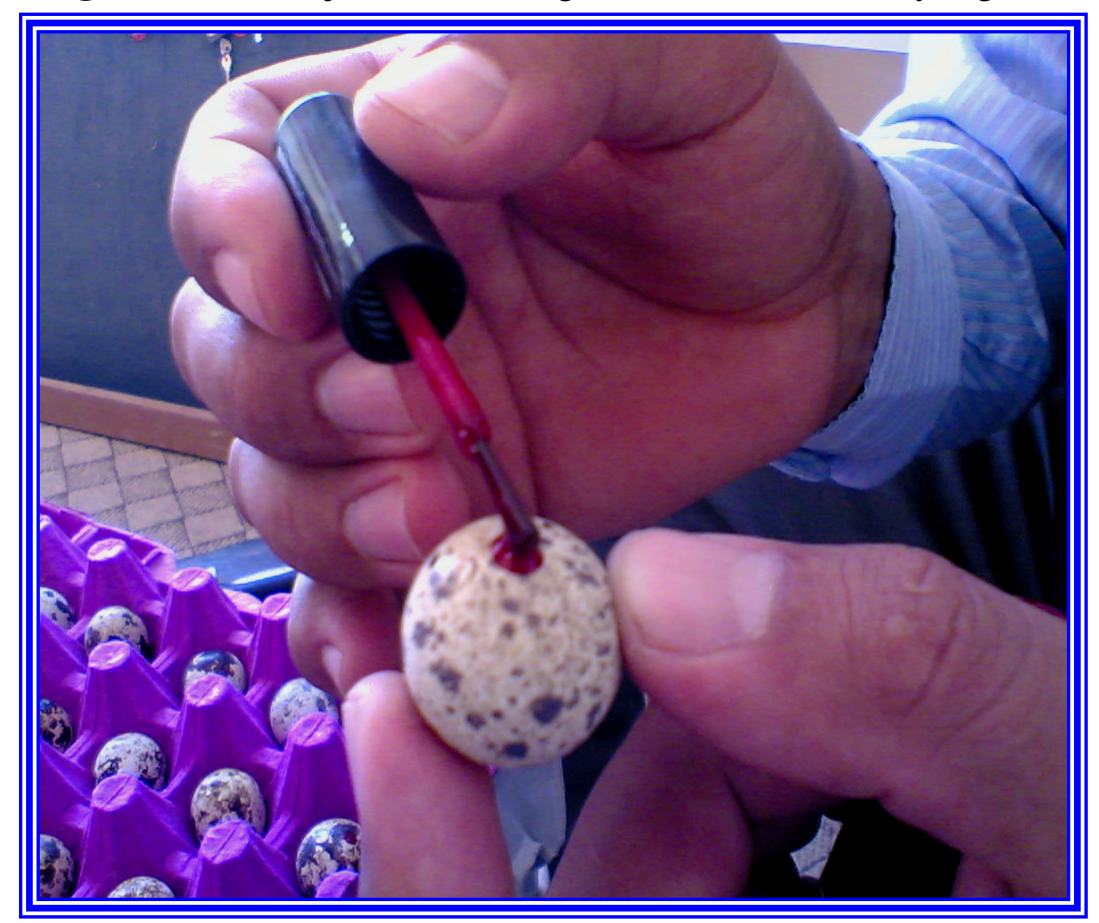

Figure 2 Sealing the injection site with nail paint. 


\section{Results and Discussion}

The effects of in ovo injection with different amounts of arginine at 0 day of age on hatchability rate are presented in Table 1 . In ovo injection with $1 \%, 2 \%$ or $3 \%$ L-arginine increased $(P \leq 0.05)$ the hatchability rate compared with the control. However, there was no significant difference in hatchability rate between T2 and T3. Initial body weight (7 days of age) and final body weight (42 days), as well as feed intake, weight gain and feed conversion from hatching to 6 weeks as affected by in ovo injection with arginine, are shown in Table 1. Results revealed that chicks produced from eggs injected with L-arginine, especially at levels $2 \%$ and 3\%, were heavier $(P \leq 0.05)$ in body weight at day 7 and at 6 weeks and showed higher weight gains $(P$ $\leq 0.05$ ) from hatch to 6 weeks than those produced from the eggs in the control. The best results of feed conversion during 0 - 6 weeks were realized in chicks hatched from eggs injected with L-arginine $(P \leq 0.05)$ compared with those hatched from control eggs. Treatment had no effect on feed intake between 0 and 6 weeks. Furthermore, there were no differences between T2 and T3 concerning initial body weight, final body weight or weight gain, while the T3 group had an improved feed conversion. Serum glucose, total protein, cholesterol, total lipids, triglycerides, calcium and phosphorus concentrations of chicks at 6 weeks differed $(P \leq 0.05)$ in the various treatments (Table 2$)$.

Table 1 Effect of in ovo injection of L-arginine on hatchability rate and productive performance of quail (means $\pm \mathrm{SE}$ )

\begin{tabular}{lcccc}
\hline \multirow{2}{*}{ Trait } & \multicolumn{4}{c}{ Treatments $^{1}$} \\
\cline { 2 - 5 } & $\mathrm{C}$ & $\mathrm{T} 1$ & $\mathrm{~T} 2$ & $\mathrm{~T} 3$ \\
\hline Hatchability (\%) & $81.3^{\mathrm{c}} \pm 2.23$ & $86.9^{\mathrm{b}} \pm 1.65$ & $90.2^{\mathrm{a}} \pm 3.31$ & $91.5^{\mathrm{a}} \pm 2.77$ \\
$\begin{array}{l}\text { Initial body weight }(7 \\
\text { days) (g) }\end{array}$ & $19.1^{\mathrm{c}} \pm 0.80$ & $20.9^{\mathrm{b}} \pm 0.76$ & $22.6^{\mathrm{a}} \pm 0.23$ & $23.1^{\mathrm{a}} \pm 0.27$ \\
$\begin{array}{l}\text { Final body weight } \\
\text { (42 days) (g) }\end{array}$ & $221^{\mathrm{c}} \pm 13.50$ & $234^{\mathrm{b}} \pm 11.25$ & $241^{\mathrm{a}} \pm 16.25$ & $246^{\mathrm{a}} \pm 19.33$ \\
Feed intake (g) & $790 \pm 55.20$ & $792 \pm 60.02$ & $795 \pm 67.13$ & $799 \pm 71.38$ \\
Body weight gain (g) & $195^{\mathrm{c}} \pm 22.19$ & $200^{\mathrm{b}} \pm 30.11$ & $211^{\mathrm{a}} \pm 29.91$ & $218^{\mathrm{a}} \pm 20.92$ \\
Feed conversion ratio & $4.04^{\mathrm{a}} \pm 0.09$ & $3.95^{\mathrm{b}} \pm 0.04$ & $3.76^{\mathrm{c}} \pm 0.06$ & $3.66^{\mathrm{d}} \pm 0.02$
\end{tabular}

C - Control group; T1, T2, and T3: represent in ovo injections of 1\%, 2\%, 3\% L-arginine, respectively.

${ }^{1}$ Means within rows with different superscripts, a - d, differ significantly at $P \leq 0.05$.

Table 2 Effect of in ovo injection of L-arginine on the concentration of blood serum traits of quail (means $\pm \mathrm{SE})$

\begin{tabular}{lcccc}
\hline \multirow{2}{*}{ Trait } & \multicolumn{4}{c}{ Treatments $^{1}$} \\
\cline { 2 - 5 } & $\mathrm{C}$ & $\mathrm{T} 1$ & $\mathrm{~T} 2$ & $\mathrm{~T} 3$ \\
\hline Glucose $(\mathrm{mg} / 100 \mathrm{~mL})$ & $253^{\mathrm{c}} \pm 24.08$ & $276^{\mathrm{b}} \pm 18.09$ & $293^{\mathrm{a}} \pm 33.15$ & $299^{\mathrm{a}} \pm 20.19$ \\
Total protein $(\mathrm{g} / 100 \mathrm{~mL})$ & $2.91^{\mathrm{c}} \pm 0.42$ & $3.28^{\mathrm{b}} \pm 0.61$ & $3.93^{\mathrm{a}} \pm 0.56$ & $4.11^{\mathrm{a}} \pm 0.36$ \\
Cholesterol $(\mathrm{mg} / 100 \mathrm{~mL})$ & $210^{\mathrm{a}} \pm 7.19$ & $183^{\mathrm{b}} \pm 9.15$ & $171^{\mathrm{c}} \pm 8.19$ & $169^{\mathrm{c}} \pm 9.75$ \\
Total lipids $(\mathrm{mg} / 100 \mathrm{~mL})$ & $695^{\mathrm{a}} \pm 29.18$ & $583^{\mathrm{b}} \pm 36.95$ & $462^{\mathrm{c}} \pm 40.01$ & $453^{\mathrm{c}} \pm 39.95$ \\
Triglycerides $(\mathrm{mg} / 100 \mathrm{~mL})$ & $190^{\mathrm{a}} \pm 9.92$ & $178^{\mathrm{b}} \pm 18.27$ & $150^{\mathrm{c}} \pm 16.91$ & $141^{\mathrm{c}} \pm 17.25$ \\
Calcium $(\mathrm{mg} / 100 \mathrm{~mL})$ & $6.03^{\mathrm{c}} \pm 0.92$ & $7.76^{\mathrm{b}} \pm 0.90$ & $8.65^{\mathrm{a}} \pm 0.72$ & $8.72^{\mathrm{a}} \pm 0.48$ \\
Phosphorus $(\mathrm{mg} / 100 \mathrm{~mL})$ & $3.72^{\mathrm{c}} \pm 0.17$ & $4.83^{\mathrm{b}} \pm 0.35$ & $5.60^{\mathrm{a}} \pm 0.29$ & $5.67^{\mathrm{a}} \pm 0.33$
\end{tabular}

C - Control group; T1, T2, and T3: represent in ovo injections of 1\%, 2\%, 3\% L-arginine, respectively.

${ }^{1}$ Means within rows with different superscripts, a $-\mathrm{c}$, differ significantly at $P \leq 0.05$. 
Chicks produced from eggs injected with $\mathrm{L}$-arginine showed significant increases $(P \leq 0.05)$ in serum glucose, protein, calcium and phosphorus concentrations and significant decreases $(P \leq 0.05)$ in serum cholesterol, total lipids and triglyceride concentrations compared with those hatched from control eggs. On the other hand, there were no significant differences between $\mathrm{T} 2$ and $\mathrm{T} 3$ for all blood serum traits included in this study.

Significant $(P \leq 0.05)$ differences were observed between treatments in carcass traits and relative weight of certain organs (Table 3 ). The overall means of carcass weight (\%) and the proportional weights of the breast, legs, liver, heart, and gizzard were higher $(P \leq 0.05)$ in chicks hatched from eggs injected with L-arginine compared with chicks produced from the control group. Moreover, chicks produced from eggs inoculated with L-arginine recorded the lowest means regarding relative weights of backbone, wing, neck and abdominal fat compared with those hatched from control eggs. However, there were no significant differences between $\mathrm{T} 2$ and $\mathrm{T} 3$ in carcass characteristics and organ weight.

Table 3 Effect of in ovo injection of L-arginine on carcass traits and proportional weight of carcass components of the quails (means $\pm \mathrm{SE}$ )

\begin{tabular}{|c|c|c|c|c|}
\hline \multirow{2}{*}{ Trait } & \multicolumn{4}{|c|}{ Treatments $^{1}$} \\
\hline & $\mathrm{C}$ & $\mathrm{T} 1$ & $\mathrm{~T} 2$ & $\mathrm{~T} 3$ \\
\hline Carcass $(\%)^{2}$ & $69.6^{c} \pm 2.63$ & $71.3^{b} \pm 1.77$ & $73.0^{\mathrm{a}} \pm 3.03$ & $73.1^{\mathrm{a}} \pm 1.23$ \\
\hline Breast $(\%)^{3}$ & $34.2^{\mathrm{c}} \pm 1.79$ & $36.1^{\mathrm{b}} \pm 2.25$ & $37.2^{\mathrm{a}} \pm 1.20$ & $37.5^{\mathrm{a}} \pm 1.08$ \\
\hline Legs $(\%)^{3}$ & $24.2^{\mathrm{c}} \pm 1.33$ & $25.9^{b} \pm 2.36$ & $26.9^{\mathrm{a}} \pm 2.08$ & $27.0^{\mathrm{a}} \pm 1.97$ \\
\hline Backbone $(\%)^{3}$ & $23.0^{\mathrm{a}} \pm 2.29$ & $22.1^{b} \pm 1.06$ & $21.0^{\mathrm{c}} \pm 0.98$ & $21.0^{\mathrm{c}} \pm 1.02$ \\
\hline Wings $(\%)^{3}$ & $7.86^{\mathrm{a}} \pm 0.92$ & $6.40^{\mathrm{b}} \pm 0.31$ & $6.03^{c} \pm 0.22$ & $5.89^{c} \pm 0.11$ \\
\hline $\operatorname{Neck}(\%)^{3}$ & $7.93^{a} \pm 0.88$ & $7.58^{b} \pm 0.76$ & $7.55^{b} \pm 0.63$ & $7.50^{b} \pm 0.80$ \\
\hline Abdominal fat $(\%)^{3}$ & $2.76^{\mathrm{a}} \pm 0.17$ & $1.93^{b} \pm 0.20$ & $1.24^{\mathrm{c}} \pm 0.11$ & $1.09^{\mathrm{c}} \pm 1.01$ \\
\hline Liver $(\%)^{3}$ & $1.45^{c} \pm 0.22$ & $1.73^{b} \pm 0.39$ & $1.95^{\mathrm{a}} \pm 0.17$ & $2.02^{\mathrm{a}} \pm 0.12$ \\
\hline Heart $(\%)^{3}$ & $0.85^{c} \pm 0.08$ & $0.93^{b} \pm 0.09$ & $1.04^{\mathrm{a}} \pm 0.11$ & $1.07^{\mathrm{a}} \pm 0.09$ \\
\hline Gizzard $(\%)^{3}$ & $1.38^{\mathrm{c}} \pm 0.09$ & $1.56^{b} \pm 0.08$ & $1.72^{\mathrm{a}} \pm 0.04$ & $1.81^{\mathrm{a}} \pm 0.06$ \\
\hline
\end{tabular}

When quail eggs were injected with L-arginine, the best results obtained in this study were recorded in productive performance, blood serum traits and carcass traits and the weights of some organs compared with those of the control treatment. This may be because arginine stimulates the secretion of the growth hormone. Campbell et al. (2004) reported that it is well documented that the infusion of arginine stimulates growth hormone secretion from the anterior pituitary. This increase in growth hormone secretion has been attributed to the suppression of endogenous somatostatin secretion (Alba-Roth et al., 1988). Darras et al. (1990; 1992) indicated that during embryonic growth, liver cells are capable of responding to the growth hormone by converting T4 to T3 and decreasing type III iodothyronine deiodinase. Moreover, hepatocytes derived from chick embryos respond to growth hormone with an increased insulin-like growth factor by continuous infusion or daily injections, and had significant beneficial effects on growth and carcass composition in young chicken (Burke et al., 1987; Cravener et al., 1989). The growth hormone exerts a broad spectrum of effects, which result in somatic growth and maintenance of fuel homeostasis. These effects include reduction in lipid synthesis, enhanced growth and protein synthesis, alterations of carbohydrate metabolism, increased levels of calcium, phosphorus, protein, glucose in blood, stimulated erythrocyte synthesis and cellular differentiations (Harvey \& Etches, 1997). Chevalley et al. (1998) and Flakoll et al. (2004) reported that arginine supplementation resulted in significant improvements in growth criteria and physiological 
performance. The in ovo fed avian neonate may have a greater capacity to digest and absorb nutrients from an exogenous diet relative to the conventional hatchling (Foey et al., 2007). Previous in ovo feeding experiments (Tako et al., 2004) demonstrated that in ovo injection of the leucin metabolite $\beta$-hydroxyl- $\beta$ methyl-butyrate had a $45 \%$ increase in jejunal villus surface area at hatch in comparison with the controls. Another possible growth potential of arginine is its role in the synthesis of creatine. Arginine, glycine and methionine are the three amino acids involved in the synthesis of creatine. Creatine has been shown to increase muscular growth and strength (Vandenberghe et al., 1997) and muscle fibre size (Volek et al., 1999). On the other hand, arginine is a precursor of the cell-signing molecule nitric oxide. Nitric oxide acts as a signalling molecule to facilitate the dilation of blood vessels and decrease vascular resistance. Nitric oxide is synthesized from arginine under the enzymatic control of nitric oxide synthase. Muscle growth and functions regulated by nitric oxide or related molecules include force production (excitation-contraction coupling), auto regulation of blood flow, myocyte differentiation, respiration and glucose homeostasis (Stamler \& Meissner, 2001). Contractile activity and muscle growth greatly increase nitric oxide production in the muscle, and this is probably because of elevated intracellular calcium (Kobzik et al., 1994).

\section{Conclusion}

It can be concluded from this study that the in ovo injection of L-arginine especially at the levels of $2 \%$ and $4 \%$ on $0 \mathrm{~d}$ of incubation would improve hatchability rate, productive performance, carcass traits and some organ weights and certain blood serum characteristics. Therefore, in ovo injection of L-arginine at 0 day old could be used as an efficient tool to improve the productive performance of Japanese quail.

\section{References}

Abiola, S.S., Meshioye, O.O., Oyerinde, B.O. \& Bamgbose, M.A., 2008. Effect of egg size on hatchability of broiler chicks. Arch. Zootech. 57, 83-86.

Alba-Roth, J., Muller, O.A. \& Schophol, J., 1988. Arginine stimulates growth hormone secretion by suppressing endogenous somatostatin secretion. J. Clin. Endocrinol. Metabol. 67, 1186-1189.

Al Daraji, H.J., Al-Hayani, W.K. \& Al-Hassani, A.S., 2008. Avian Hematology. Ministry of Higher Education and Scientific Research, University of Baghdad, College of Agriculture.

Al-Murrani, W.K., 1978. Maternal effects on embryonic and postembryonic growth in poultry. Br. Poult. Sci. 19, 277-281.

Burke, W.H., Moore, J.A., Ogez, J.R. \& Builder, S.E., 1987. The properties of recombinant chicken growth hormone and its effect on growth, body composition, feed efficiency, and other factors in broiler chickens. Endocrin. 120, 651-658.

Campbell, B.I., LaBounty, P.M. \& Roberts, M., 2004. The ergogenic potential of arginine. J. Int. Soc. Sport Nutr. 1 (2), 35-38.

Chevalley, T., Rizzoli, R., Mannen, D., Caverzasio, J. \& Bonjour, J.P., 1998. Arginine increases insulin-like growth factor-I production and collagen synthesis in osteoblast-like cells. Bone 23, 103-109.

Cravener, T.L., Vasilatos-Younken, R. \& Wellenreitter, R.H., 1989. Effect of subcutaneous infusion of pituitary-derived chicken growth hormone on growth performance of broiler pullets. Poult. Sci. 68, 1133-1140.

Darras, V.M., Huybrchts, L.M., Berghman, L., Kuhn, E.R. \& Decuypere, E., 1990. Ontogeny of the effect of purified chicken growth hormone on the liver 5 ' monodeiodination activity in the chicken: reversal of the activity after hatching. Gener. Compar. Endocrin. 77, 212-220.

Darras, V.M., Berghman, L.R., Vanderpooten, S.M. \& Kuhn, E.R., 1992. Growth hormone actually decreases type III iodothyronine deiodinase in chicken liver. FEBS Letters 310, 5-8.

Dibner, J.J., Knight, C.D., Kitchell, M.L., Atwell, C.A., Downs, A.C. \& Ivey, F.J., 1998. Early feeding and development of the immune system in neonatal poultry. J. Appl. Poult. Res. 7, 425-436.

dos Santos, T.T., Corzo, A., Kidd, M.T., McDaniel, C.D., Torres Filho, R.A. \& Araujo, L.F., 2010. Influence of in ovo inoculation with various nutrients and egg size on broiler performance. J. Appl. Poult. Res. $19,1-12$.

Elaroussi, M.A., Deluca, H.F., Forte, L.R. \& Biellier, H.V., 1993. Survival of vitamin D-deficient embryos: Time and choice of cholecalciferol or metabolites for treatment in ovo. Poult. Sci. 72, 1118-1126. 
Foye, O.T., Uni, Z. \& Ferket, P.R., 2006. Effect of in ovo feeding egg white protein, $\beta$-hydroxyl- $\beta$ methylbutyrate, and carbohydrates on glycogen status and neonatal growth of turkeys. Poult. Sci. 85, 1185-1192.

Foye, O.T., Ferket, P.R. \& Uni, Z., 2007. The effects of in ovo feeding arginine, $\beta$-hydroxyl- $\beta$-methylbutyrate, and protein on jejunal digestive and absorptive activity in embryonic and neonatal turkey poults. Poult. Sci. 86, 2343-2349.

Flakoll, P., Sharp, R., Baier, S., Levenhagen, D., Carr, C. \& Nissen, S., 2004. Effect of $\beta$-hydroxyl- $\beta$ methylbutyrate, arginine, and lysine supplementation on strength, functionality, body composition, and protein metabolism. Nutr. 20, 444-451.

Harvey, S. \& Etches, R.J., 1997. Perspectives in Avian Endocrinology. J.W. Arrowsmith Ltd, Bristol, UK.

Kobzik, L., Reid, M.B., Bredt, D.S. \& Stamler, J.S., 1994. Nitric-oxide in skeletal muscle. Nature 372, 546548.

Narushin, V.G. \& Romanov, M.N., 2002. Egg physical characteristics and hatchability. J. Wrld's Poult. Sci. 58, 297-302.

Ohta, Y., Kidd, M.T. \& Ishibashi, T., 2001. Embryo growth and amino acid concentration profiles of broiler breeder eggs, embryos, and chicks after in ovo administration of amino acids. Poult. Sci. 80, 14301436.

Ohta, Y., Tsushima, N., Koide, K., Kidd, M.T. \& Ishibashi, T., 1999. Effect of amino acid injection in broiler breeder eggs on embryonic growth and hatchability of chicks. Poult. Sci. 78, 1493-1498.

O' Neill, I.E., Houston, B. \& Goddard, C., 1990. Stimulation of insulin - like growth factor I production in primary cultures of chicken hepatocytes by chicken growth hormone. Molec. Cell. Endocr. 70, 41-47.

Petek, M., Baspinar, H. \& Ogan, M., 2003. Effects of egg weight and length of storage on hatchability and subsequent growth performance of quail. S. Afr. J. Anim. Sci. 33, 242-247.

SAS, 2000. SAS/STAT User's Guide, Version, 6.12. Inst. Inc., Cary, N.C., USA.

Stamler, J. \& Meissner, G., 2001. Physiology of nitric oxide in skeletal muscle. Physiol. Rev. 81, 209-237.

Steel, R.G.D. \& Torrie, J.H., 1980. Principles and Procedures of Statistics: A Biometrical Approach. $2^{\text {nd }}$ ed. McGraw-Hillbook Co., NY.

Tako, E., Ferket, P.R. \& Uni, Z., 2004. Effects of in ovo feeding of carbohydrates and $\beta$-hydroxyl- $\beta$ methylbutyrate on the development of chicken intestine. Poult. Sci. 83, 2023-2028.

Tong, B.C. \& Barbul, A., 2004. Cellular and physiological effects of arginine. Mini Rev. Med. Chem. 4 (8), 823-832.

Uni, Z., Tako, E., Gal-Garber, O. \& Sklan, D., 2003. Morphological, molecular and functional changes in the chicken small intestine of the late-term embryo. Poult. Sci. 82, 1747-1754.

Vandenberghe, K., Goris, M., Van Hecke, P. \& Van Leemputte, M.A., 1997. Long-term creatine intake is beneficial to muscle performance and pharmacokinetic considerations. J. Appl. Physiol. 83, 2055-2063.

Volek, J.S., Duncan, N.D., Mazzetti, S.A. \& Putukian, M., 1999. Performance and muscle fiber adaptations to certain supplementation and heavy resistance training. Med. Sci. Sports Excerc. 31, 1147-1156.

Wu, G. \& Morris, S.M., 1998. Arginine metabolism: nitric oxide and beyond. Biochem. J. 336, 1-17. 